\title{
Rancang Bangun Sistem Informasi Penyewaan menggunakan Metode Waterfall
}

\author{
Pebri Damayanti $^{1}$, Siti Masripah ${ }^{2}$
}

\begin{tabular}{ll}
\hline \multicolumn{2}{l}{ Info Artikel } \\
\hline & \\
Diterima & Desember, 18, 2020 \\
Revisi & Januari, 18, 2021 \\
Terbit & Maret, 30, 2021 \\
& \\
\hline
\end{tabular}

\section{Keywords:}

Rentals

Waterfall

Design

\begin{abstract}
PT)
The rental is an agreement or agreement made by the two parties concerned during a predetermined period of time and at an agreed price. Today there are already many companies moving in the field of room rental services complete with its facilities, this makes many room rental services users perform room rentals for the purposes of the events they will implement. To that endeavor in this field desperately requires systems that can support to improve customer service. At this time there were still many companies moving in the field using still-manual systems, ranging from customers wishing to conduct room rentals having to go to the company. As for the record keeping of customer booking data still done manually can lead to customer rental schedule errors, a subscriber rental data redundancy occurs. The methods used to address such problems are the development of waterfall systems (Analyses of system needs, Design, Code Generation, Testing, Support) and web-based information systems. From the development of the system used can address problems such as the occurrence of rental schedule data errors and others, resulting in accurate information and the achievement of an effective and efficient activity.
\end{abstract}

\section{Identitas Penulis:}

Pebri Damayanti ${ }^{1}$, Siti Masripah ${ }^{2}$

Sistem Informasi Akuntansi Kampus Kota Bogor Universitas Bina Sarana Informatika, Komplek Pesona Intiland Jl.Raya Cilebut, Kel.Sukaresmi, Kec.Tanah Sareal, Kota Bogor Febridamayanti22@gmail.com ${ }^{1}$,Siti.stm@bsi.ac.id ${ }^{2}$

\section{PENDAHULUAN}

Perkembangan teknologi yang semakin pesat sekarang ini telah membawa dampak dalam kehidupan masyarakat, sehingga menuntut kita untuk mengikuti arus perkembangan teknologi tersebut, seperti pemanfaatan teknologi komputer salah satunya adalah sistem informasi. Sistem informasi banyak ditawarkan dengan tujuan untuk memberikan kemudahan bagi para pengguna untuk menghasilkan informasi yang dapat dipercaya, relevan, tepat waktu, lengkap, dapat dipahami, dan teruji.[1]

Penggunaan sistem informasi dapat digunakan di suatu bagian perusahaan, seperti halnya yang dilakukan dalam pengelolaan manajemen gedung (building management) yang membutuhkan informasi secara real time dalam memberikan pelayanan yang efektif dan optimal kepada pelanggan.[2]

Dalam penelitian yang dilakukan Ramdani dan Husaein menyatakan bahwa perusahaan yang masih menggunakan sistem secara manual dapat menimbulkan beberapa permasalahan seperti terjadinya redundansi data, terdapat kesulitan dalam melakukan pencarian data pelanggan dan pembuatan laporan yang memerlukan waktu yang relatif tidak singkat. [2]. Untuk itulah, maka dibuat suatu website yang dapat menanggulangi masalah tersebut. Website ini akan memberikan kemudahan kepada pelanggan, dan pihak perusahaan. [3]. Sistem penyewaan yang dirancang menggunakan metode SDLC (Sistem Development Live Cycle), yaitu tahapan Analisa, desain, pembuatan kode, pengujian dan pendukung [4]. Sistem informasi yang ada akan berjalan dengan baik jika sudah dilakukan pengujian, pengujian black box dilakukan untuk mengetahui apakah sistem tersebut dapat dinyatakan valid sesuai dengan yang diharapkan [5]. Pengujian 
adalah kegiatan dimana suatu sistem atau komponen dieksekusi dibawah kondisi tertentu, hasilnya diamatai atau dicatat untuk kemudian diecaluasi berdasarkan aspek siste atau komponen [6]. Berdasarkan latar belakang tersebut, maka sistem penyewaan yang baik membutuhkan sebuah sistem informasi penyewaan yang mendukung kegiatan promosi Gedung untuk disewa, transaksi penyewaan, serta laporan-laporan transaksi guna membantu pemilik usaha untuk menjalankan usaha penyewaannya dengan mudah.

\section{METODE} adalah :

Dalam usaha mendapatkan data yang jelas dan akurat terhadap penelitian maka metode yang digunakan

1. Observasi (Observation)

Melakukan observasi dengan cara melihat dari beberapa contoh sistem penyewaan ruangan melalui internet.

2. Studi Pustaka (Library Research)

Studi kepustakaan melalui literature, buku yang berkaitan dengan permasalahan.

Metode Pengembangan Software, metode yang digunakan pada perkembangan perangkat lunak ini menggunakan model Waterfall yang terbagi menjadi lima tahapan menurut Rosa dan Shalahuddin dalam [4] yaitu:

1. Analisa Kebutuhan Sistem

Proses pengumpulan kebutuhan dilakukan secara intensif untuk menspesifikasikan kebutuhan perangkat lunak agar dapat dipahami seperti: dapat melihat harga ruangan beserta fasilitasnya, memesan ruangan secara online, mengelola data pemesanan, dan melakukan transaksi pembayaran.

2. Desain

Desain perangkat lunak adalah proses multi/langkah yang fokus pada desain pembuatan program perangkat lunak termasuk struktur data, arsitektur perangkat lunak, dan prosedur pengkodean. Pada tahap ini dibuat Struktur Navigasi untuk mendesain halaman web, serta UML (Unified Modelling Language) untuk menggambarkan alur sistem.

3. Code Generation

Pada tahap ini sudah mulai memasukan script kode pemrograman kedalam sebuah software programming untuk dapat menghasilkan desain yang sudah dibuat yakni menggunakan bahasa pemrograman PHP (Hypertext Preprocessor), HTML (Hyper Text Markup Language), JavaScript, CSS (Cascading Style Sheets), Sublime Text 3 untuk Text Editor dan MySQL untuk Database Management System (DBMS).

4. Testing

Untuk melakukan evaluasi kemampuan dari program atau sistem yang dibuat dilakukan pengujian dengan menggunakan blackbox testing yaitu pengujian perangkat lunak dari segi spesifikasi fungsional tanpa menguji desain dan kode program. Hal ini dilakukan untuk meminimalisir kesalahan (eror) dan memastikan apakah website yang dibuat sesuai dengan yang diharapkan.

5. Support

Tidak menutup kemungkinan sebuah perangkat lunak mengalami perubahan ketika sudah dikirimkan ke user. Perubahan bisa terjadi karena adanya kesalahan yang muncul dan tidak terdeteksi saat pengujian atau perangkat lunak harus beradaptasi dengan lingkungan baru. Tahap pendukung atau pemeliharaan dapat mengulangi proses pengembangan mulai dari analisis spesifikasi untuk perangkat lunak yang sudah ada, tapi tidak untuk membuat perangkat lunak baru.

\section{HASIL}

Dalam metode waterfall yang pertama dilakukan adalah Analisa kebutuhan software, dengan melakukan Analisa terhadap proses bisnis yang terjadi yaitu 1)Proses Pemesanan, Proses pemesanan diawali dengan pelanggan mengunjungi website Sewa Ruangan, bagi pelanggan yang belum mempunyai akun pelanggan melakukan daftar terlebih dahulu. Namun bagi pelanggan yang sudah memiliki akun bisa langsung masuk kehalaman web (login). Setelah pelanggan melakukan login, maka pelanggan bisa mencari ruangan beserta tanggal sewa ruangan yang dibutuhkan setelah itu bisa memilih ruangan dan lama sewa, jika ruangan yang dicari tidak tersedia atau sudah terapakai maka pelanggan bisa mencari ruangan yang lain atau dengan waktu yang lain dan jika ruangan tersedia pelanggan bisa melanjutkan proses pemesanan ruangan. 2)Proses Pembayaran, setelah pelanggan memesan ruangan, pelanggan dapat melihat detail pesanan \& detail pembayaran setelah itu pelanggan bisa melakukan pembayaran melalui bank transfer dengan maksimal waktu pembayaran 1 jam. Setelah pelanggan dapat melakukan konfirmasi pembayaran yang terdapat pada halaman web. Admin akan mengecek konfimasi pembayaran. Setelah itu admin dapat merubah status pemesanan 
menjadi berhasil serta mencetak dan pelanggan bukti pemesanan dapat mencetak bukti pemesanan. 3)Proses Pembuatan Laporan Merupakan proses terakhir yaitu melaporkan kegiatan penjualan setiap bulannya kepada pimpinan perusahaan yang data-datanya diambil melalui transaksi pemesanan perharinya.

Penggambaran yang dilakukan menggunakan diagram aktivitas, akan menghasilkan bentuk seperti gambar 1, dibawah ini :

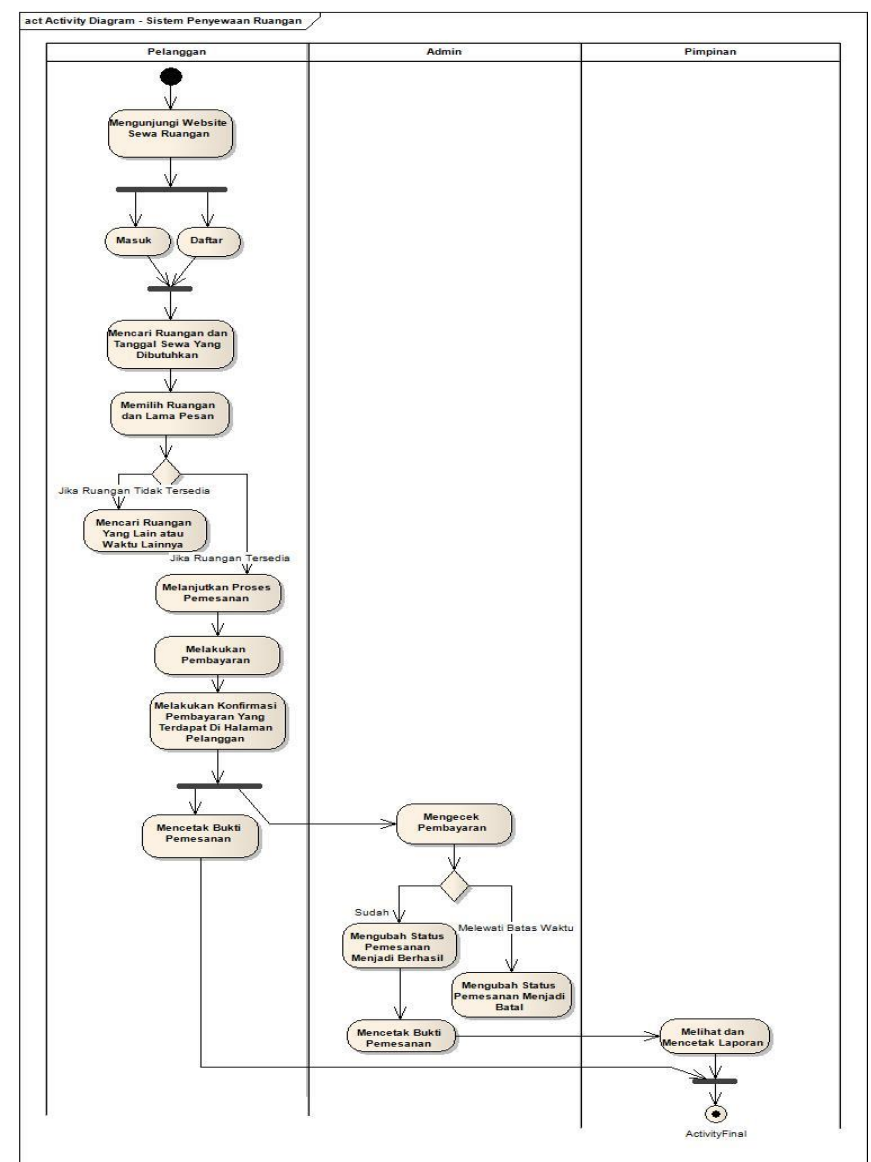

Sumber : penelitian mandiri (2020)

Gambar 1. Diagram Activity penyewaan ruangan

\subsection{Analisa Kebutuhan Fungsional}

Setelah mengetahui bagaimana proses bisnis yang berjalan pada penyewaan ruangan, maka dapat dibuat Analisa kebutuhan fungsional akan sistem yang dibuat yaitu :

1. Pelanggan

a) Melakukan pendaftaran

b) Melakukan login ke sistem

c) Melihat panduan sewa ruangan

d) melihat peraturan dan tentang sewa ruangan

e) Melakukan pencarian ruangan

f) Melakukan pemesanan ruangan

g) Melakukan konfirmasi pembayaran

2. Admin

a) Melakukan login ke sistem

b) Melihat jaswal pemesanan harian

c) Mengelola data admin

d) Mengelola data ruangan

e) Mengelola data pelanggan

f) Mengelola data pesanan

g) Melihat dan mencetak laporan 
3. Pimpinan

a) Melakukan login ke sistem

b) Melihat jadwal pemesanan harian

c) Melihat dan mencetak laporan

Setelah Analisa kebutuhan sudah dibuat, maka digambarkan menggunakan diagram UML yaitu use case diagram, berikut use case diagram untuk Pelanggan dapat dilihat pada gambar 2. Use case pelanggan

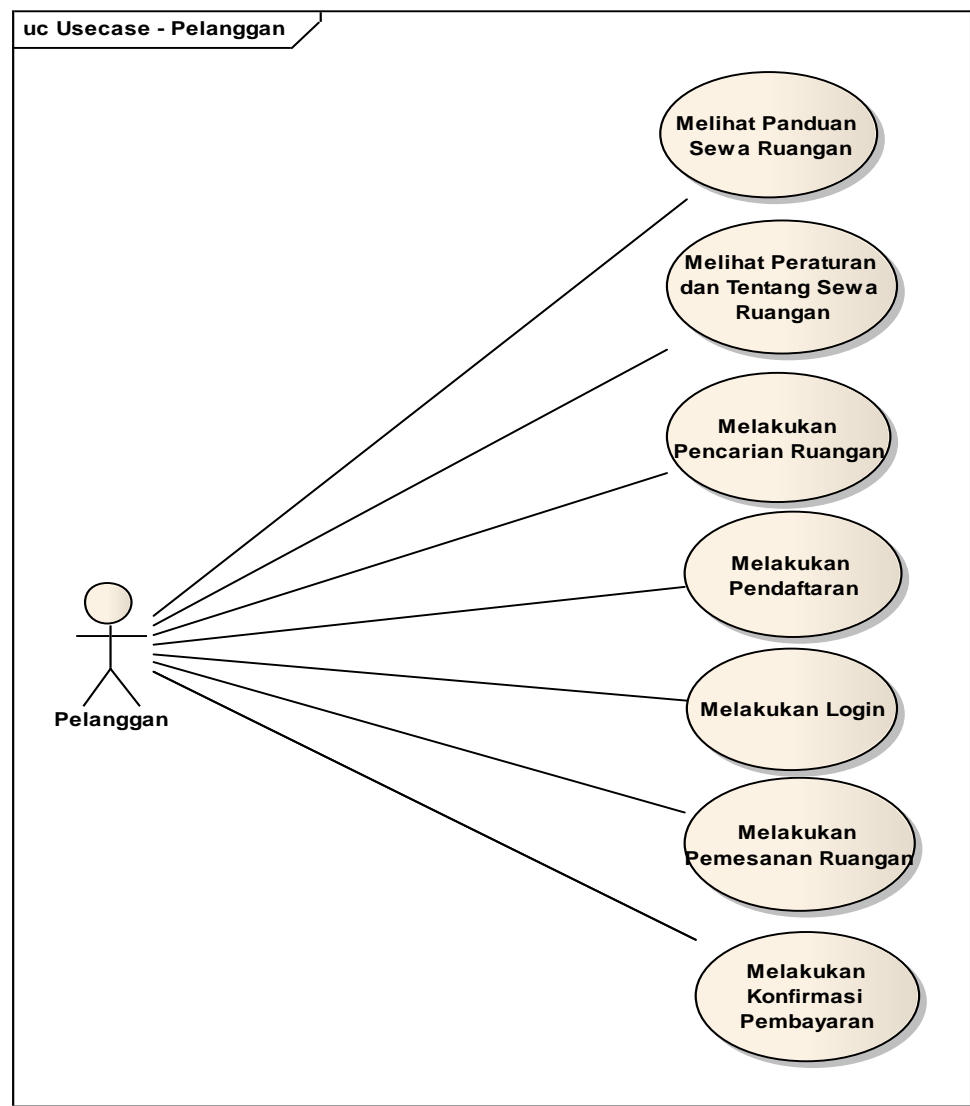

sumber:penelitian mandiri(2020)

Gambar 2. Use Case Diagram Pelanggan 
Vol. 02, No. 01, Maret 2021, pp. 30 41

ISSN: 2721-7523

Berikut adalah gambar diagram use case untuk admin, dapat dilihat pada gambar 3.

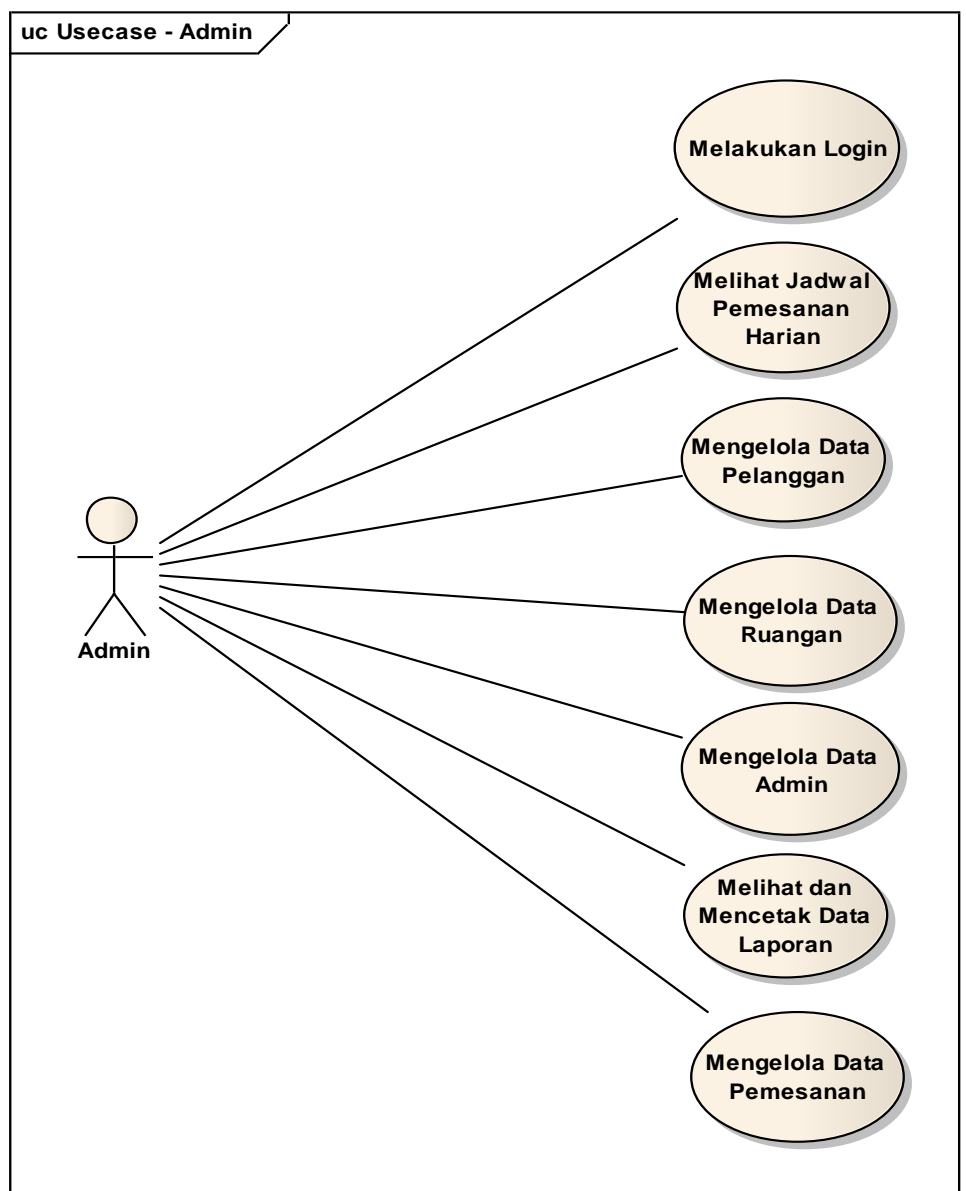

Sumber : penelitian mandiri (2020)

Gambar 3. Use Case Diagram Admin

Berikut adalah gambar 4, menggambarkan tentang diagram use case untuk pimpinan.

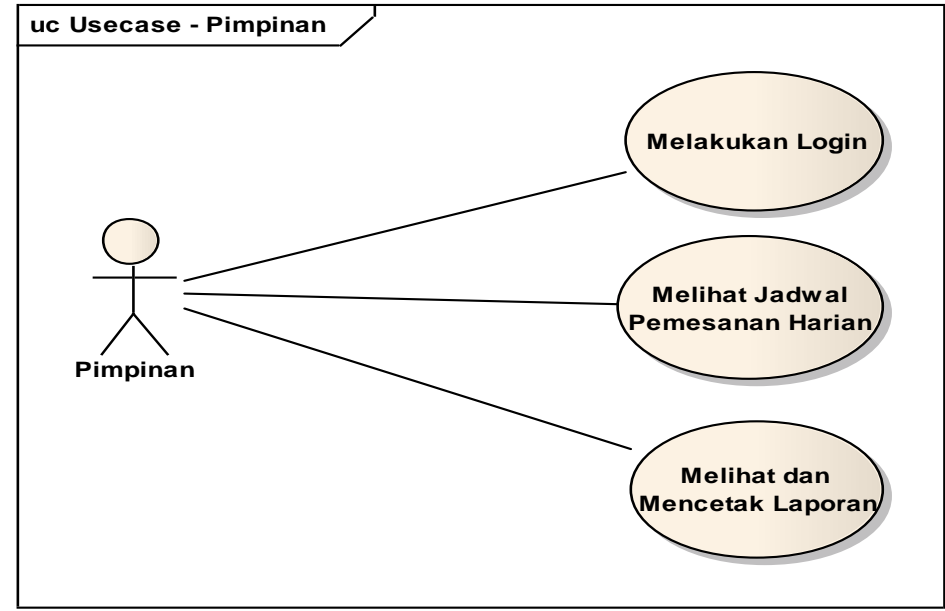

Sumber : penelitian mandiri (2020)

Gambar 4. Use Case Diagram Pimpinan 
Setelah Analisa kebutuhan digambarkan menggunakan use case diagram, maka berikutnya akan diperjelas pada diagram activity, berikut penulis gambarkan diagram activity untuk konfirmasi pembayaran dapat dilihat pada gambar 5 dan mengelola data pesanan dapat dilihat pada gambar 6 .

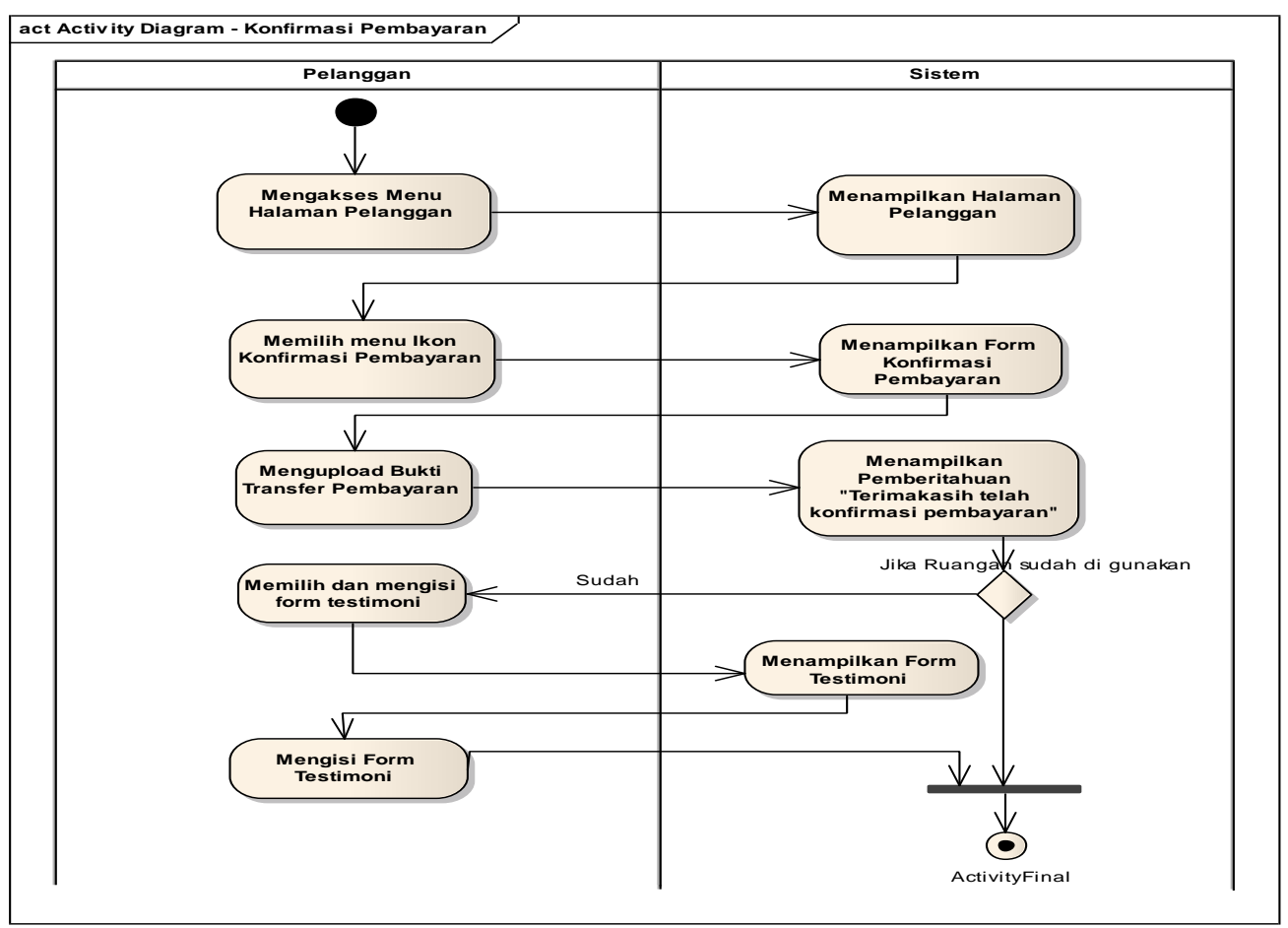

Sumber : Penelitan mandiri(2020)

Gambar 5. Activity diagram konfirmasi pembayaran

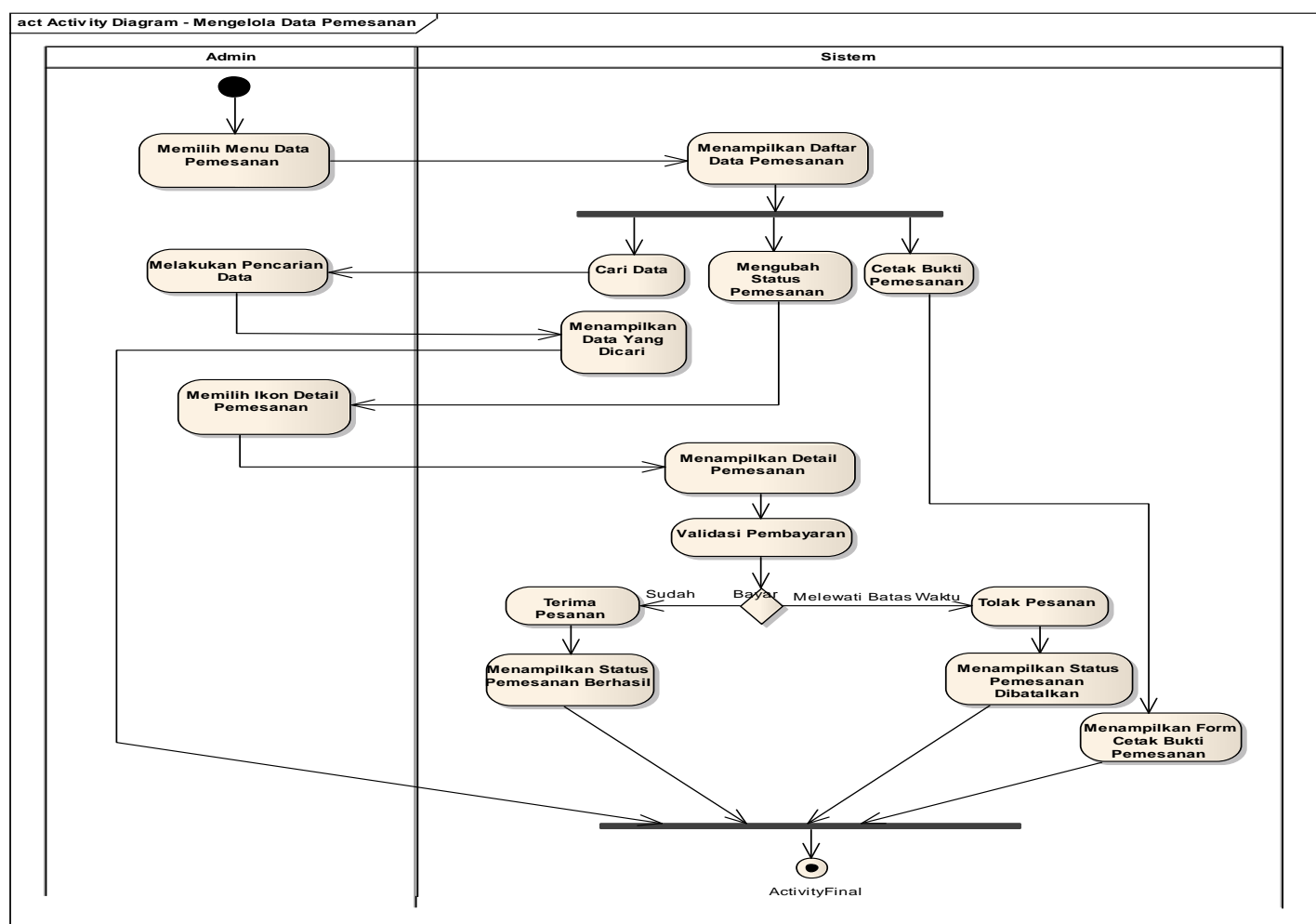

Sumber : Penelitian mandiri (2020)

Gambar 6. Activity diagram mengelola data pemesanan 
Vol. 02, No. 01, Maret 2021, pp. 30 41

ISSN: 2721-7523

Setelah menggambarkan tentang activity diagram selanjutnya adalah membuat sequence diagram pada gambar 7 untuk login admin dan gambar 8 untuk mengelola data ruangan.

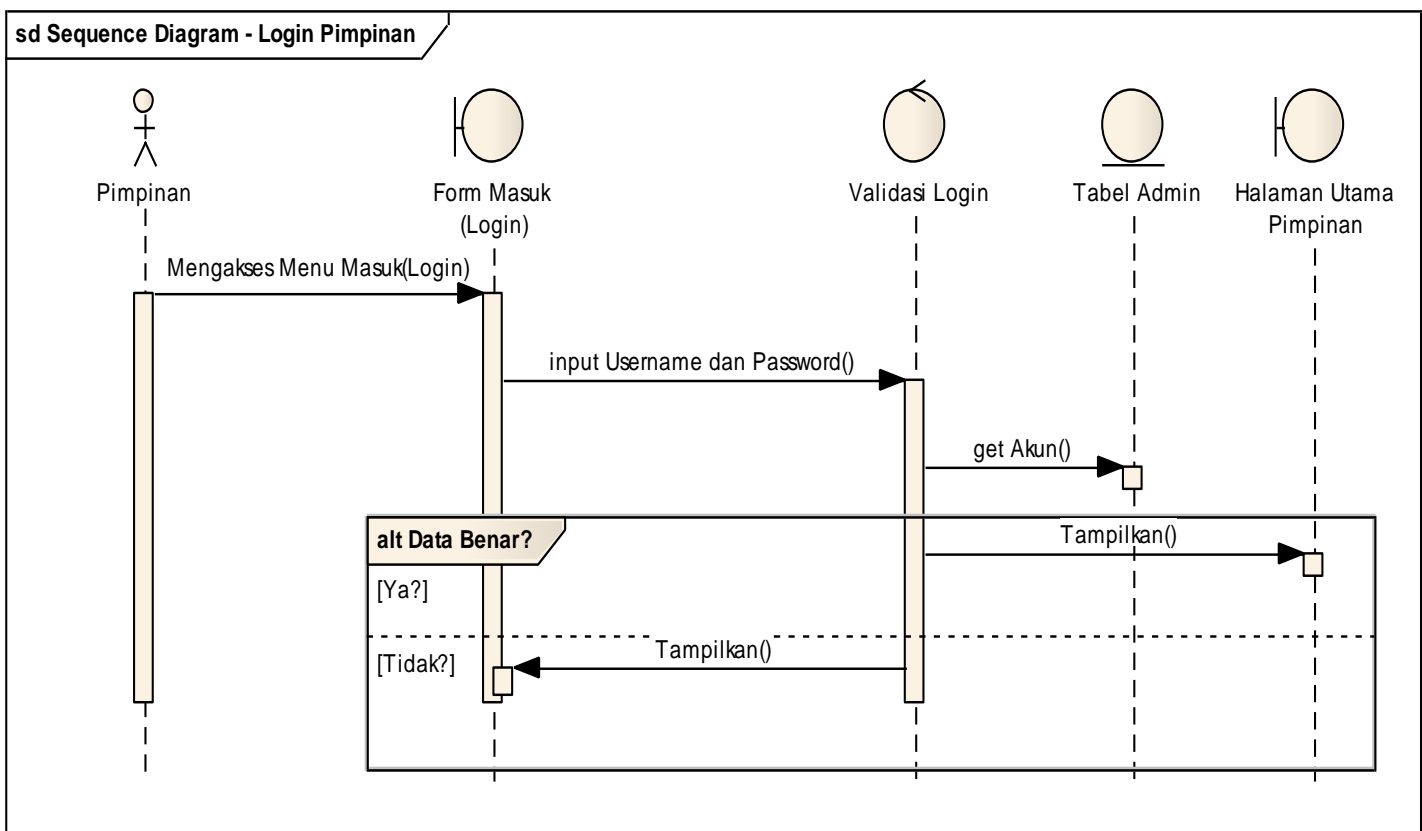

Sumber : penelitian mandiri (2020)

Gambar 7. Sequence diagram log in admin

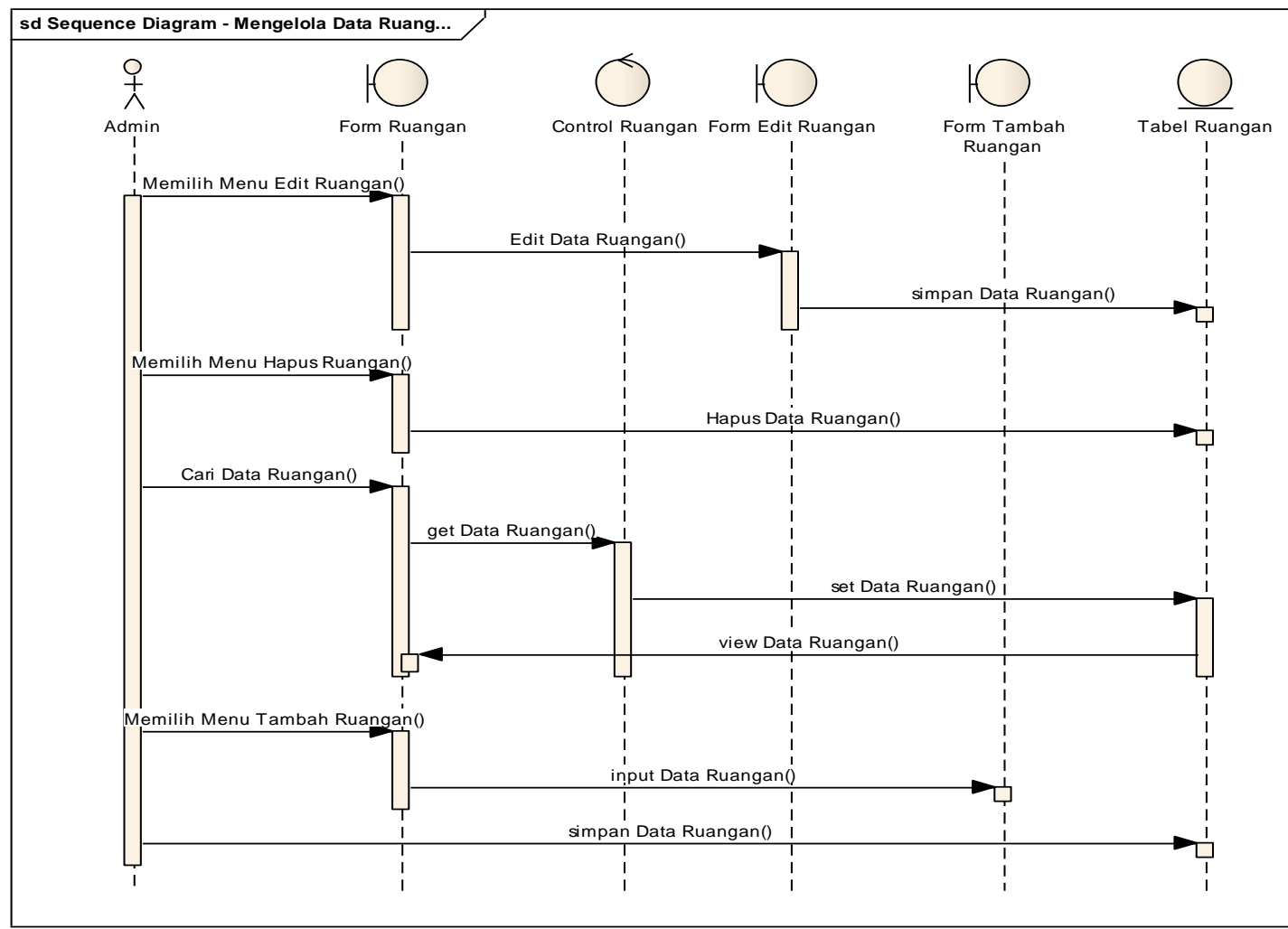

Sumber : penelitian mandiri(2020)

Gambar 8. Sequence diagram mengelola data ruangan 


\subsection{Desain}

Pada tahapan desain, penulis membuatkan struktur navigasi untuk pelanggan, berikut tampilannya dapat dilihat pada gambar 9.

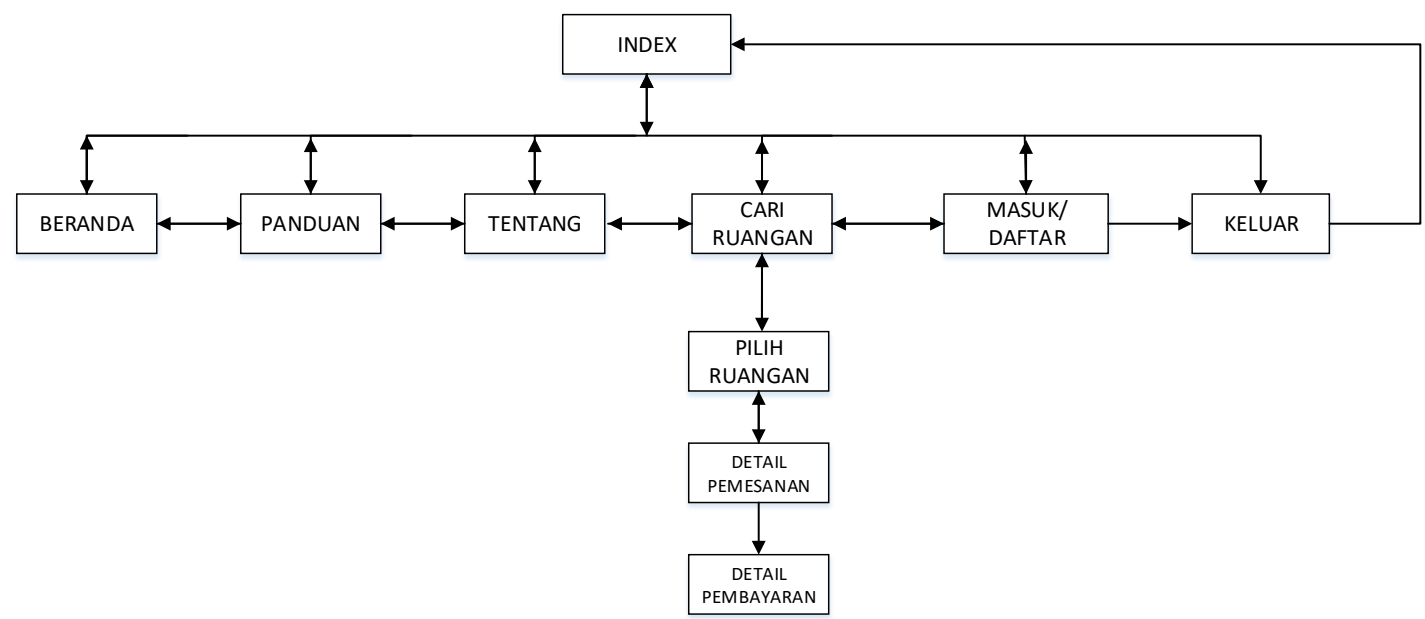

Sumber : penelitian mandiri(2020)

\section{Gambar 9. Struktur Navigasi pelanggan}

Tahapan desain berikutnya adalah membuat struktur class diagram pada gambar 10, yang nantinya akan diterapkan dalam Bahasa pemprograman dalam tahapan implementasi.

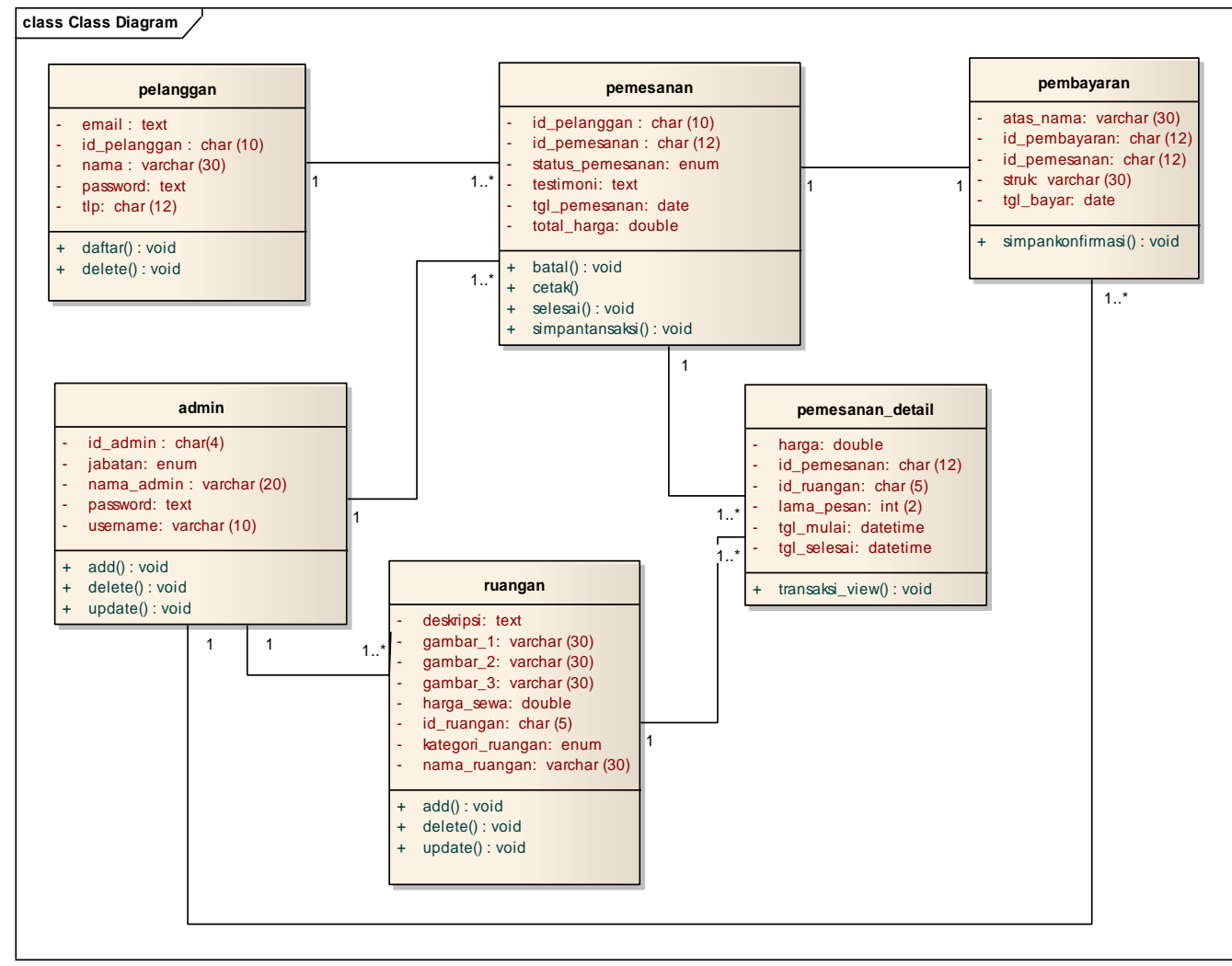

Sumber : penelitian mandiri (2020)

Gambar 10. Class diagram 
Selanjutnya tahapan desain untuk user interface, penulis membuatkan user interface untuk masuk kedalam system (login) dan halaman pemesanan ruangan.

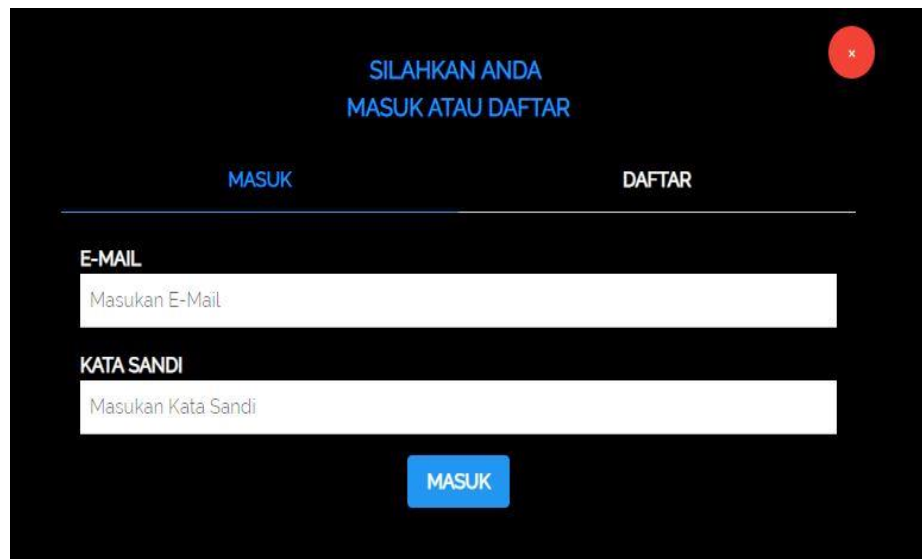

Sumber : penelitian mandiri (2020)

Gambar 11. User interface Login

Pada Gambar 11, user diberikan kesempatan untuk mengisi data email dan kata sandi sehingga dapat masuk kedalam system penyewaan ruagan. Jika user belum memiliki akses, user dapat melakukan pendaftaran terlebih dahulu.

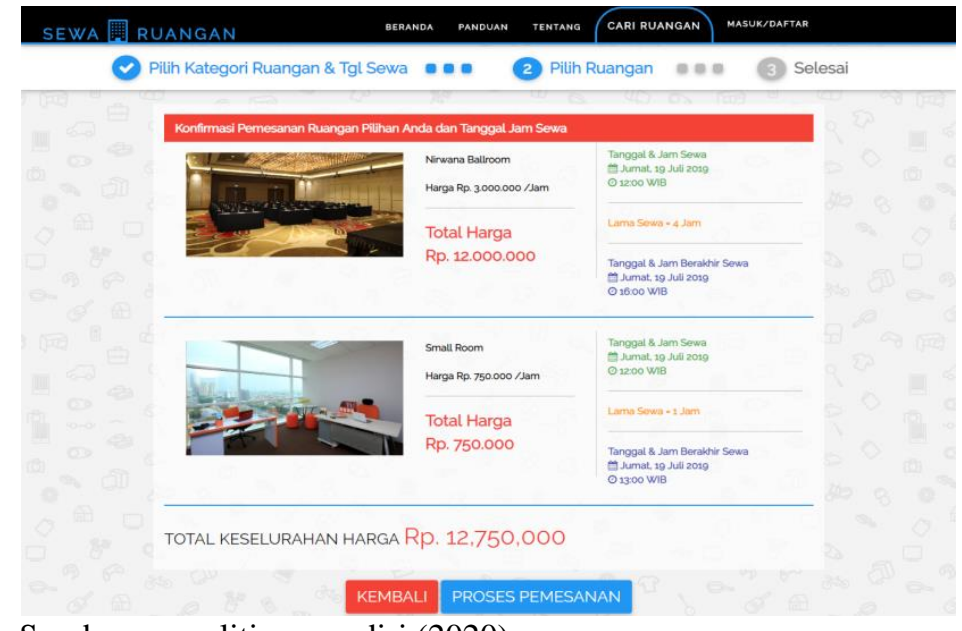

Sumber : penelitian mandiri (2020)

Gambar 12. User interface Pemesanan Ruangan

Pada Gambar 12, merupakan gambar user interface untuk pemesanan ruangan yang akan dilakukan oleh pelanggan. Pelanggan dapat memilih jenis ruangan yang akan disewa dan dapat melihat harga sewa serta keterangan lainnya.

\subsection{Implementasi}

Pada tahapan implementasi, dilakukan penerapan kedalam bahasa pemprograman menggunakan PHP dengan database MySQL. Berikut contoh implementasi yang dilakukan yaitu code generation login :

function aksi_login ()\{

$$
\begin{aligned}
& \text { \$email }=\$ \text { this- }>\text { input- }>\text { post ('email'); } \\
& \text { \$password = \$this->input->post('password'); } \\
& \text { \$kat_ruang=\$this->input->post('kat_ruang'); } \\
& \text { \$tgl_mulai=\$this->input->post('tgl_mulai'); } \\
& \text { \$ruang }=\$ \text { this }->\text { input }->\text { post('ruang'); } \\
& \text { \$lama_sewa }=\text { \$this->input->post('lama_sewa'); } \\
& \text { \$where = array }( \\
& \text { 'email' => \$email, }
\end{aligned}
$$




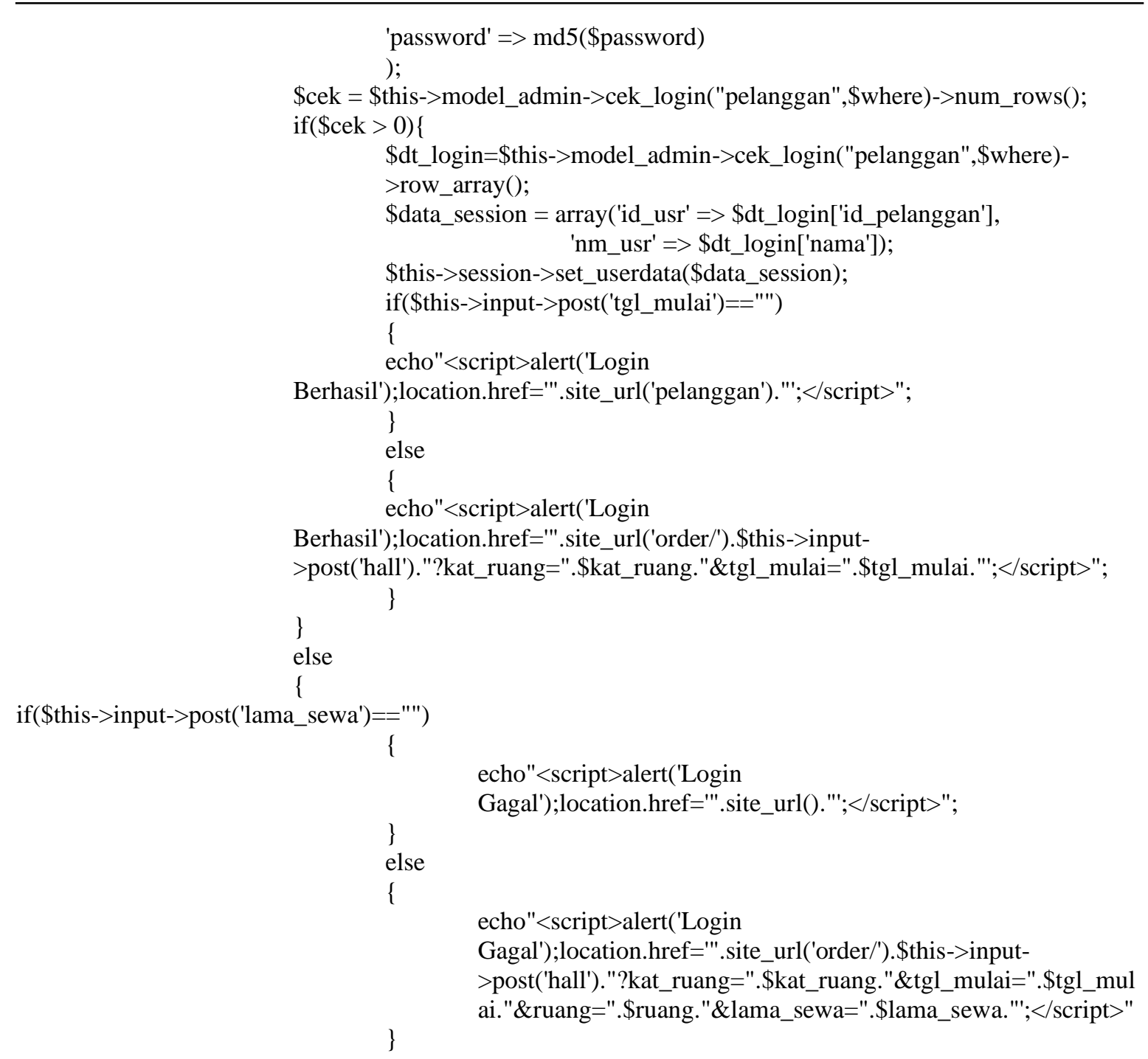

\subsection{Pengujian}

Pada tahapan terakhir adalah tahapan pengujian, sebuah system yang akan diterapkan harus melakukan tahap pengujian terlebih dahulu, guna mendapatkan umpan balik dari system yang telah dibuat.pengujian dilakukan menggunakan Black Box Testing. Berikut pengujian yang ditampilkan adalah pengujian pada user interface login dan user interface Tambah ruangan.

1. Pengujian Terhadap Form Login Pelanggan

Tabel 1.

Hasil Pengujian Black Box Testing Form Login Pelanggan

\begin{tabular}{|c|c|c|c|c|c|}
\hline No & $\begin{array}{l}\text { Skenario } \\
\text { Pengujian }\end{array}$ & Test case & Hasil yang diharapkan & $\begin{array}{c}\text { Hasil } \\
\text { pengujian }\end{array}$ & Kesimpulan \\
\hline \multirow[t]{4}{*}{1.} & Email dan & Email : & Sistem akan menolak & \multirow{4}{*}{$\begin{array}{c}\text { Sesuai } \\
\text { harapan }\end{array}$} & \multirow[t]{3}{*}{ Valid } \\
\hline & Kata Sandi tidak & (kosong) & akses user dan & & \\
\hline & diisi kemudian & Kata Sandi : & Menampilkan "Maaf & & \\
\hline & klik tombol & (kosong) & Email dan Kata Sandi & & \\
\hline
\end{tabular}




\begin{tabular}{|c|c|c|c|c|c|}
\hline & masuk & & Masih kosong" & & \\
\hline \multirow[t]{5}{*}{2.} & Email disi dan & Email : & Sistem akan menolak & \multirow{5}{*}{$\begin{array}{l}\text { Sesuai } \\
\text { harapan }\end{array}$} & \multirow[t]{5}{*}{ Valid } \\
\hline & Kata Sandi tidak & Isi & akses user dan & & \\
\hline & diisi kemudian & Kata Sandi : & Menampilkan "Maaf & & \\
\hline & klik tombol & (kosong) & Kata Sandi masih & & \\
\hline & Masuk & & kosong" & & \\
\hline \multirow[t]{5}{*}{3.} & Email tidak diisi & Email : & Sistem akan menolak & \multirow{5}{*}{$\begin{array}{l}\text { Sesuai } \\
\text { harapan }\end{array}$} & \multirow[t]{5}{*}{ Valid } \\
\hline & dan Kata Sandi & (kosong) & akses user dan & & \\
\hline & diisi kemudian & Kata Sandi : & Menampilkan "Maaf & & \\
\hline & klik tombol & isi & Email masih kosong" & & \\
\hline & \multicolumn{3}{|l|}{ masuk } & & \\
\hline \multirow[t]{8}{*}{4.} & Mengetikan & Email : & Sistem akan menolak & \multirow{8}{*}{$\begin{array}{l}\text { Sesuai } \\
\text { harapan }\end{array}$} & \multirow[t]{8}{*}{ Valid } \\
\hline & salah satu & isi (benar) & akses user dan & & \\
\hline & kondisi salah & Kata Sandi : & Menampilkan "Login & & \\
\hline & pada Email & isi (salah) & gagal" & & \\
\hline & \multicolumn{3}{|l|}{ atau Kata } & & \\
\hline & \multicolumn{3}{|l|}{ sandi kemudian } & & \\
\hline & \multicolumn{3}{|l|}{ klik tombol } & & \\
\hline & \multicolumn{3}{|l|}{ masuk. } & & \\
\hline
\end{tabular}

\section{Tabel 2.}

Hasil Pengujian Black Box Testing Form Tambah Ruangan

\begin{tabular}{|c|c|c|c|c|c|}
\hline No & $\begin{array}{r}\text { Skenario } \\
\text { Pengujian }\end{array}$ & Test case & Hasil yang diharapkan & $\begin{array}{c}\text { Hasil } \\
\text { pengujian }\end{array}$ & Kesimpulan \\
\hline 1 & $\begin{array}{l}\text { Nama Ruangan } \\
\text { tidak diisi } \\
\text { (kosong) }\end{array}$ & $\begin{array}{l}\text { Nama } \\
\text { Ruangan : } \\
\text { (kosong) }\end{array}$ & $\begin{array}{l}\text { Sistem akan menolak } \\
\text { akses user dan } \\
\text { menampilkan "Maaf, }\end{array}$ & \multirow[t]{2}{*}{$\begin{array}{c}\text { Sesuai } \\
\text { harapan }\end{array}$} & \multirow[t]{2}{*}{ Valid } \\
\hline & $\begin{array}{l}\text { kemudian klik } \\
\text { tombol Simpan } \\
\text { Data Ruangan }\end{array}$ & & $\begin{array}{l}\text { Nama Ruangan masih } \\
\text { kosong". }\end{array}$ & & \\
\hline \multirow[t]{2}{*}{2.} & Harga Sewa & Harga Sewa & Sistem akan menolak & \multirow[t]{2}{*}{$\begin{array}{l}\text { Sesuai } \\
\text { harapan }\end{array}$} & \multirow[t]{2}{*}{ Valid } \\
\hline & (kosong) & & menampilkan "Maaf, & & \\
\hline
\end{tabular}




\begin{tabular}{|c|c|c|c|c|c|}
\hline & kemudian klik & & Harga Sewa masih & & \\
\hline & tombol Simpan & & Kosong”. & & \\
\hline & Data Ruagan & & & & \\
\hline \multirow[t]{5}{*}{3} & Deskripsi tidak & Deskripsi : & Sistem akan menolak & \multirow{6}{*}{$\begin{array}{l}\text { Sesuai } \\
\text { harapan }\end{array}$} & Valid \\
\hline & Diisi (kosong) & (kosong) & akses user dan & & \\
\hline & kemudian klik & & menampilkan "Maaf, & & \\
\hline & tombol Simpan & & Deskripsi masih & & \\
\hline & Data Ruagan & & kosong". & & \\
\hline \multirow[t]{3}{*}{4.} & Pada kolom & Gambar 1,2 & Sistem akan menolak & & \\
\hline & gambar $1,2,3$ & 3 : (No File & akses user dan & & \\
\hline & $\begin{array}{l}\text { gambar tidak } \\
\text { dipilih } \\
\text { kemudian klik } \\
\text { tombol Simpan } \\
\text { Data Ruangan }\end{array}$ & chosen) & $\begin{array}{l}\text { menampilkan "Maaf, } \\
\text { Gambar 1,2 ,3 masih } \\
\text { kosong". }\end{array}$ & Sesuai & Valid \\
\hline
\end{tabular}

\section{KESIMPULAN}

Berikut kesimpulan dari rancang bangun system penyewaan ruangan yaitu :

a. Program yang dibangun dalam sistem penyewaan ruangan ini bersifat dinamis sehingga memudahkan admin untuk mengelola seperti input data,hapus data, dan update data.

b. Dengan adanya website penyewaan ruangan ini diharapkan dapat mempermudah calon pelanggan dalam melakukan pemesanan ruangan secara online dimana saja dan kapan saja.

c. Para calon pelanggan dapat mengetahui informasi mengenai tarif ruangan tanpa harus datang ke kantor tersebut.

d. Sistem yang berbasis web ini juga meringankan pekerjaan para pegawai dalam mengelola seluruh datadata yang ada dimana media penyimpanan yang menggunakan database akan menjamin lebih aman dan lebih dapat menyimpan data dalam jumlah banyak, dan dapat mencegah terjadinya duplicate record.

e. Sebuah rancangan system harus melakukan tahap pengujian, sehingga hasil yang diharapkan akan sesuai dengan apa yang dirancang.

\section{REFERENSI}

[1] H. T. Sitohang, "Sistem Informasi Pengagendaan Surat Berbasis Web Pada Pengadilan Tinggi Medan," $J$. Inform. Pelita Nusant. Vol. 3 No 1 Maret 2018 e-ISSN 2541-3724, vol. 3, no. 1, pp. 6-9, 2018.

[2] Ramdani and T. Husain, "Analisis Dan Peracangan Sistem Informasi Penyewaan,” vol. 01, no. 02, pp. 1-7, 2017.

[3] A. Prasetyo, Y. N. N. P, P. Studi, and M. Informatika, "Angsuran Pinjaman Pada Koperasi Pegawai Republik Indonesia ( Kpri ) Pemerintah Daerah Kabupaten Malang,”vol. 4, no. 1, pp. 27-40, 2013.

[4] H. Larasati and S. Masripah, "Analisa dan perancangan sistem informasi pembelian grc dengan metode waterfall," Pilar Nusa Mandiri, vol. 13, no. 2, pp. 37-42, 2017.

[5] S. Masripah and L. Ramayanti, "Pengujian Black Box Pada Sistem Informasi Penerimaan Siswa Baru Berbasis Web," vol. 4, no. 1, pp. 1-12, 2019.

[6] D. Galin, Software Quality Concepts and Practile (1st ed). New Jersey: Wiley, 2018. 